\title{
Inhalt, Vol. 7, No. 5, 1984
}

\section{Contents}

Impressum 258

K. O. Schmid, GrazlÖsterreich

Histologische Subtypen des Bronchuskarzinoms und deren biologisches Verhalten 260

Sonderbände 262

Denck, H. und Kutschera, W., Wien-Lainz/Österreich

Das Bronchialkarzinom aus chirurgischer Sicht 263

Hinweise für Autoren 266

A. Hackl, GrazlÖsterreich

Die Therapie des Bronchuskarzinoms aus der Sicht des

Strahlentherapeuten 268

Rab, B. undSabitzer, H., KlagenfurtlÖsterreich

Co-Referat zu »Therapie des Bronchialkarzinoms aus der

Sicht des Strahlentherapeuten« 273

H. Rainer, Wien/Österreich

Chemotherapie des kleinzelligen Bronchuskarzinoms . . 276

O. Kokron, Wien-Lainz/Österreich

Chemotherapie des nicht-kleinzelligen Bronchuskarzi

noms 285

Jakse, R. und Lehnert, M. , GrazlÖsterreich

Biologisches Tumorverhalten und kurative Primär-

therapie bei HNO-Tumoren 293

Lehnert, M.; Jakse, R. und Seewann, H. L.,

GrazlÖsterreich

Chemotherapie bei fortgeschrittenem Plattenepithel-

karzinom des HNO-Bereiches 297

Scherpe, A.; Schroder, M.; von Hey den, H.-W. und

Nagel, G. A., Göttingen

Chemotherapieergebnisse mit Cisplatin und 5-Fluoro-

uracil bei Plattenepithelkarzinomen des Kopf-Hals-

Bereiches 302

Gatzemeier, U.; Zschaber, R.; Hossfeld, D. K. und Radenbach, D., Hamburg

Cisplatin, Vindesin und VP 16-213 in der Behandlung des

inoperablen nicht-kleinzelligen Bronchialkarzinoms. -

Eine klinische Phase-II-Studie

308

Neuigkeiten für die klinische Praxis 316

Buchbesprechungen 318 
Histological Subtypes of the Bronchus Carcinoma and their Biological Behavior 260

Special Editions 262

Denck, H. and Kutschera, W., Wien-Lainz/Österreich

Bronchogenic Carcinoma from the Surgeon's Point of

View 263

Instructions for Authors 266

A. Hackl, GrazlÖsterreich

Therapy of Lung Cancer Out of a Radiotherapeutic Point

of View 268

Rab, B. and Sabitzer, H., KlagenfurtlÖsterreich

Radiotherapy of the Bronchial Carcinoma 273

H. Rainer, Wien/Österreich

Chemotherapy of Oat Cell Carcinoma 276

O. Kokron, Wien-Lainz/Österreich

Chemotherapy in Non-Small Cell Lung Cancer

Jakse, R. and Lehnert, M. , GrazlÖsterreich

Biology and Curative Primary Therapy of Head and

Neck Tumors 293

Lehnert, M.; Jakse, R. and Seewann, H. L.,

GrazlÖsterreich

Chemotherapy in Advanced Head and Neck Squamous

Cell Carcinoma 297

Scherpe, A.; Schroder, M.; von Hey den, H.-W. and

Nagel, G. A., Göttingen

Results of Chemotherapy with Cisplatin and 5-Fluo-

rouracil in Squamous Cell Carcinoma of the Head and

Neck Region 302

Gatzemeier, U.; Zschaber, R.; Hossfeld, D. K. and Radenbach, D., Hamburg

Cisplatinum, Vindesine and VP 16-213 in the Treatment

of Inoperable Non-Small Cell Lung Cancer. - A Phase-II

Trial 308

News for Clinical Practice 316

Book Reviews 318

Oncology Communications 320

Bibliographischer Hinweis: Inhaltsverzeichnisse dieser Zeitschrift erscheinen regelmäßig in current contents ${ }^{\circledR}$ sowie in anderen bibliographischen Diensten. 